\title{
Effect of Cement Replacement with Carbide Waste on the Strength of Stabilized Clay Subgrade
}

\author{
Muntohar, A.S. ${ }^{*}$, Hartono, E. ${ }^{1}$, Diana, W. ${ }^{1}$, and Rahmawati, A. ${ }^{1}$
}

\begin{abstract}
Cement is commonly used for soil stabilization and many other ground improvement techniques. Cement is believed to be very good to improve the compressive and split-tensile strength of clay subgrades. In some application cement could be partly or fully replaced with carbide waste. This research is to study the effectiveness of the cement replacement and to find the maximum carbide waste content to be allowed for a clay subgrade. The quantities of cement replaced with the carbide waste were $30,50,70,90$, and $100 \%$ by its mass. The results show that replacing the cement with carbide waste decreased both the compressive and split tensile strength. Replacing cement content with carbide waste reduced its ability for stabilization. The carbide waste content should be less than $70 \%$ of the cement to provide a sufficient stabilizing effect on a clay subgrade.
\end{abstract}

Keywords: Carbide waste; cement replacement; soil stabilization; split tensile strength; subgrade; unconfined compressive strength.

\section{Introduction}

Expansive soil is known as problematic soil causing detrimental effect on pavement system. A case of pavement deterioration over the expansive soil in Yogyakarta has been investigated by Muntohar [1]. Cement stabilized soil technique has been applied successfully in pavement base layers [2]. In recent years, the utilization of waste materials has received considerable attention. Reuse of waste materials in construction has several benefits; to reduce the disposal costs incurred by industry, and ultimately providing sustainable development and economic growth. Some waste materials have properties that allow utilization as pavement materials either as a structural or replacement components. One of the potential waste materials to be reused is carbide waste.

Carbide waste contains calcium material that is a by-product from the production of acetylene gas $\left(\mathrm{C}_{2} \mathrm{H}_{2}\right)$. The waste is generated as a slurry that comprised of $85-95 \%$ calcium hydroxide $\left(\mathrm{Ca}(\mathrm{OH})_{2}\right)$, minor parts of calcium carbonate $\left(\mathrm{CaCO}_{3} \approx 1-10 \%\right)$, and unreacted carbon and silicates (1-3\%) [3]. In general, calcium hydroxide $\left(\mathrm{Ca}(\mathrm{OH})_{2}\right)$ of the carbide waste is generated from the reaction between water $\left(\mathrm{H}_{2} \mathrm{O}\right)$ and calcium carbide $\left(\mathrm{CaC}_{2}\right)$ as;

\footnotetext{
${ }^{1}$ Department of Civil Engineering, Universitas Muhammadiyah Yogyakarta, INDONESIA

* Corresponding author; e-mail: muntohar@umy.ac.id
}

Note: Discussion is expected before June, $1^{\text {st }} 2016$, and will be published in the "Civil Engineering Dimension" volume 18, number 2, September 2016.

Received 10 May 2014 revised 13 Novermber 2015; accepted 22 December 2016.
$\mathrm{CaC}_{2}+2 \mathrm{H}_{2} \mathrm{O} \rightarrow \mathrm{C}_{2} \mathrm{H}_{2}+\mathrm{Ca}(\mathrm{OH})_{2}$

The carbide waste from acetylene gas $\left(\mathrm{C}_{2} \mathrm{H}_{2}\right)$ production is usually disposed of by landfilling, which may create further problems, i.e. the leaching of harmful compounds and alkali to groundwater. Application of the carbide waste in soil stabilization has been investigated in combination with cement or other cementitious materials [4-8].

Cement and its various form has been the most widely used stabilization agent for clay and sandy soil. In the soil stabilization with waste materials, cement was used to activate fly ash and ground granulated blast-furnace slag (GGBFS). Consoli et al. [5] and Xi et al. [6] used carbide waste as an activator to replace cement partially in combination with fly ash and GGBFS for soil stabilization. Their studies showed that the carbide lime controlled the initial stages of strength gain. Based on the previous research, a research need to further investigate on the carbide waste replaced cement for soil stabilization especially on the effect of the compressive and tensile strength. Thus, the purpose of this research is to define the effectiveness of the cement replacement and to find the maximum carbide wastes content to be allowed for a clay subgrade. Variables evaluated were compressive strength, tensile strength, and a range of curing times.

\section{Experimental Methods}

\section{Soils}

The soils were taken from Kasihan, Yogyakarta, Indonesia. The geotechnical properties of the soil are 
presented in Table 1. The grain size distribution curve of the soil is shown in Figure 1. According to the Unified Soil Classification System [9], the soil specimen was classified as high plasticity clay $(\mathrm{CH})$, while the soil was grouped into A-7-5 according to AASHTO classification [10].

Table 1. Index and Geotechnical Properties of the Soil Used

\begin{tabular}{ll}
\hline Properties & Value \\
\hline Specific gravity & 2.63 \\
Grain size: & \\
$\quad$ Sand & $11 \%$ \\
Silt & $42 \%$ \\
Clay & $47 \%$ \\
Consistency limits: & \\
$\quad$ Liquid limit & $84 \%$ \\
Plastic limit & $29 \%$ \\
Plasticity index & $55 \%$ \\
Compaction (Standard Proctor): & \\
$\quad$ Maximum dry density, MDD & $11.05 \mathrm{kN} / \mathrm{m}^{3}$ \\
$\quad$ Optimum moisture content, OMC & $28 \%$ \\
Natural moisture content & $10-70 \%$ \\
Unconfined compressive strength & $32 \mathrm{kPa}$ \\
Split-tensile strength & $3.26 \mathrm{kPa}$ \\
Swelling index & 0.078 \\
Mineral & $\mathrm{Na}-\mathrm{Montmorillonite}$ \\
\hline
\end{tabular}

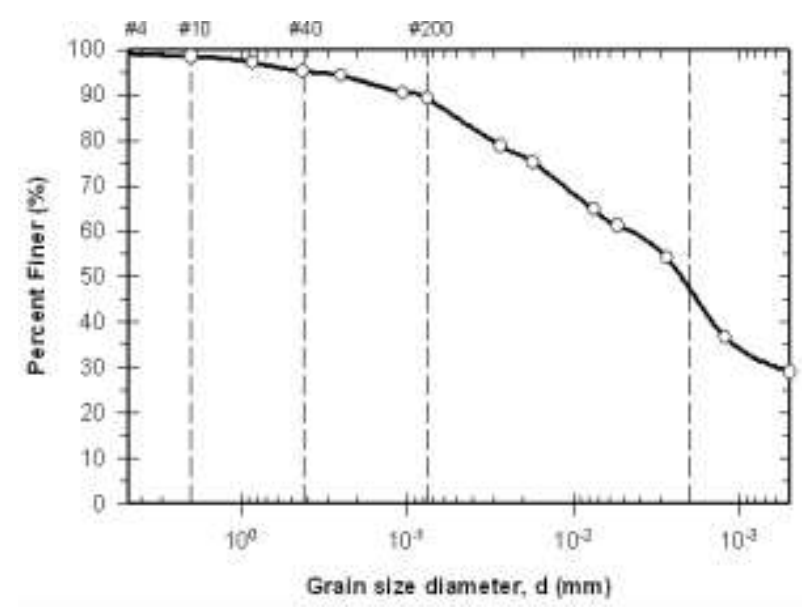

Figure 1. The Grain Size Distribution of the Soil Sample

\section{Stabilization Materials}

The stabilizers used in this research consisted of the cement and carbide waste $(\mathrm{CW})$. The cement was Type I Portland cement composite produced by PT. Holcim Indonesia Tbk. The cement was mainly compounded with C3S (60\%), C2S (22\%), and C4AF $(18 \%)$. The chemical composition of the cement is presented in Table 2 . The CW was collected from the disposal area of the electroplating industry in Sedayu, Yogyakarta, Indonesia. The raw CW consisted of wet powder and granulated particles. Then, the CW was sun-dried for 2-3 days to reduce its high moisture content. For the final stage of drying, the $\mathrm{CW}$ was dried at $105^{\circ} \mathrm{C}$ for $24 \mathrm{~h}$ in an electrical oven. The oven dried CW was ground in the Los Angeles Abrasion Machine for 2 hours to provide an acceptable fineness. The $\mathrm{CW}$ predominantly consisted of $\mathrm{CaO}, \mathrm{Al}_{2} \mathrm{O}_{3}, \mathrm{SiO}_{2}$, and minor metallic oxides ( $\mathrm{Fe}, \mathrm{Na}, \mathrm{K}, \mathrm{Mg}, \mathrm{Mn}$ ) which are all lower than $0.25 \%$ (Table 2). The CW was composed of $81 \%$ portlandite mineral, which consists of calcium hydroxide, as the primary crystalline phase, about $19 \%$ carbonate and carbon in light quantity (Figure 2).

Table 2. Chemical Composition of the Cement and Carbide Waste

\begin{tabular}{lcc}
\hline Elements & Cement (\%) & Carbide Waste (\%) \\
\hline $\mathrm{Al}_{2} \mathrm{O}_{3}$ & 5.80 & 8.80 \\
$\mathrm{CaO}$ & 63.9 & 57.40 \\
$\mathrm{Fe}_{2} \mathrm{O}_{3}$ & 3.40 & 0.11 \\
$\mathrm{MgO}$ & 1.10 & 0.098 \\
$\mathrm{Na}_{2} \mathrm{O}$ & 0.20 & 0.012 \\
$\mathrm{~K}_{2} \mathrm{O}$ & 0.30 & 0.03 \\
$\mathrm{MnO}$ & 0.002 & 0.0004 \\
$\mathrm{SiO}_{2}$ & 20.4 & 3.40 \\
$\mathrm{SO}_{3}$ & 1.98 & 0.10 \\
Loss on Ignition (LOI) & 2.90 & 30.05 \\
\hline
\end{tabular}

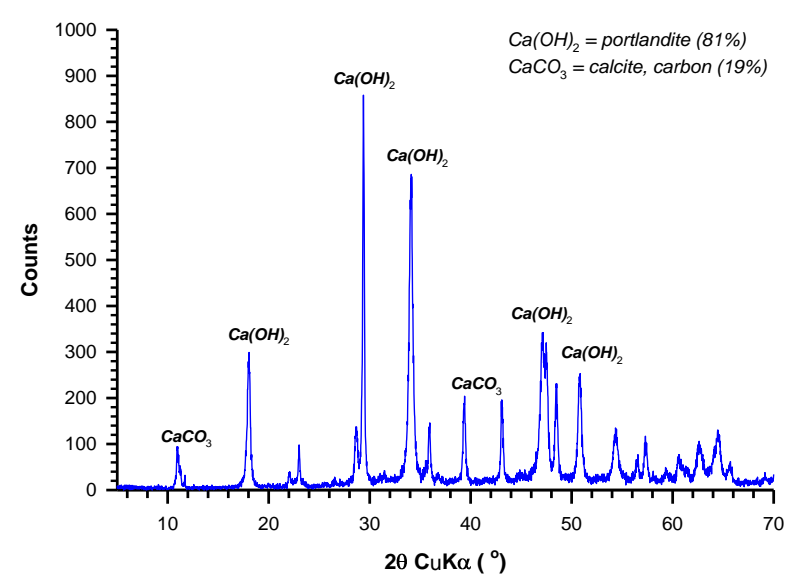

Figure 2. X-ray Diffractograms of the Carbide Waste

\section{Experimental Program}

Series of the laboratory testing was undertaken to evaluate the influence of mixture proportion of the carbide waste and cement for soil stabilization. Two primary laboratories testing conducted were unconfined compressive strength and split tensile strength. A cylindrical specimen of $50 \mathrm{~mm}$ in diameter by 100 $\mathrm{mm}$ in length was used for the experiments. The percentage by mass of cement and carbide waste for stabilization is presented in Table 3. The amount of cement required for stabilization was determined from the relationship between the plasticity index and various cement content (Figure 3). The required cement content for stabilization was determined from the cement fixation point. The cement fixation point is the transitional point that the dramatic change in plasticity index turns to the little change in plasticity index. In this study, the cement fixation 
point was at $10 \%$ of dry weight of soil. The specimens were moist cured after molded for 1, 7, 14, and 28 days to study the influence of curing time on the strength.

Table 3. Mixtures Design and Testing Program

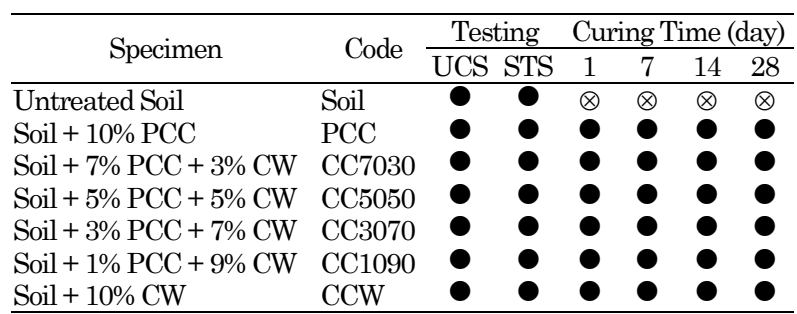

o: tested; $\otimes$ : not-tested; $\mathrm{PCC}=$ cement; $\mathrm{CW}$ : carbide waste; UCS: unconfined compressive strength test; STS: splittensile strength test. All the percentage of PCC and CW are by weight of dry soil

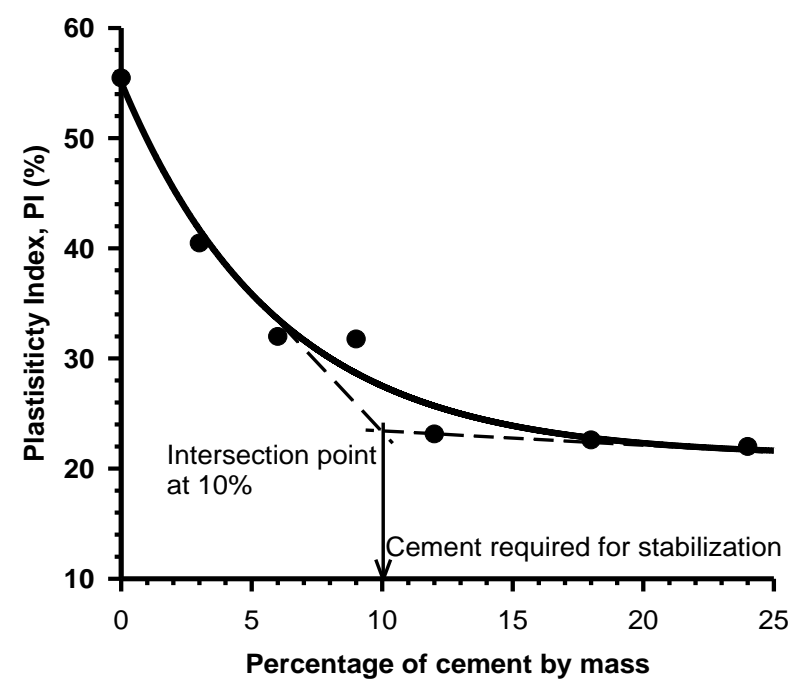

Figure 3. Determination of Percentage of Cement Required for Stabilization

\section{Specimen Preparation and Testing Procedure}

Both treated and untreated soil samples were prepared at optimum moisture content in accordance with the data from the standard proctor test (see Table 1) to control the effect of density and moisture. Each specimen was statically compacted in a cylindrical mold. Afterward, the specimen was dismantled from the mold. The mass of the specimen was determined immediately after preparation and then kept in a plastic bag for particular days of curing. For the cement-stabilized soil, the mass of cement was $10 \%$ of the dry mass of soil. For the cement - carbide waste mixture, the quantities of cement was replaced accordingly based on the ratio as presented in Table 3. In Table 3, specimen CC7030, refers to cement content of $7 \%$ and $3 \%$ carbide waste; whereas for specimen CC1090, the mixture composition was $1 \%$ cement and $9 \%$ carbide waste. All the materials were weighed in dry conditions.
The unconfined compression test was determined in accordance with ASTM D5102-04 for the stabilized soils [11]. The force was applied so that the strain rate was approximately $1 \mathrm{~mm} /$ minute until specimen failure. The split tensile test procedure was ASTM C496-96 [12] deals with the determination of tensile strength. The strain rate was approximately $1 \mathrm{~mm} /$ minute until specimen failure

\section{Results and discussion}

\section{Unconfined Compressive Strength and Split Tensile Strength}

The variation of the unconfined compressive strength with the percent of carbide waste is shown in Figures 4a and b. In general, unconfined compressive strength decreases with decreasing of the percentage of cement in the soil mixture. Cement stabilized clay enhanced the unconfined compressive strength of clay considerably from $32 \mathrm{kPa}$ (see Table 1) to $1200 \mathrm{kPa}(1.2 \mathrm{MPa})$ and $3010 \mathrm{kPa}(3.01 \mathrm{MPa})$ after one and 28 days of curing respectively. Whereas, the unconfined compressive strength of the carbide waste mixed clay increased slightly from $32 \mathrm{kPa}$ to $380 \mathrm{kPa}(0.38 \mathrm{MPa})$ and $590 \mathrm{kPa}(0.59 \mathrm{MPa})$ after one and 28 days of curing respectively. Reducing cement portion in the cement - carbide waste - soil mixtures result in decreasing the unconfined compressive strength. It was observed in Figure 4a that there was little change in unconfined compressive strength if the carbide content was less than $3 \%$ in the mixtures. The percent of reduction in unconfined compressive strength is presented in Figure 4b. The best-fit line in Figure 4b shows that the unconfined compressive strength decreased about one-half after $70 \%$ cement replacement with carbide waste. Full replacement of cement (stabilized with carbide waste solely), caused about 80\% strength reductions.

Tensile strength is an important parameter for understanding and predicting the shrinkage cracking potential and flexural fatigue potential of subgrade [13]. The effect of cement and cementcarbide mixture on tensile strength increase is an important design consideration for pavement. The tensile strength of untreated soil was very low about $3.26 \mathrm{kPa}$ (Table 1). Experimental results of this study show that addition cement, as OPC specimens, increases the tensile strength in the range of 0.67 $\mathrm{MPa}$ to $1.09 \mathrm{MPa}$ after one to 28 days of curing. Figure 5a illustrates the variation of the split tensile strength with the percent of carbide waste in the soil - cement mixtures. Similar to the unconfined compressive strength, replacing cement content with a carbide waste in the mixtures results in decreasing tensile strength. 


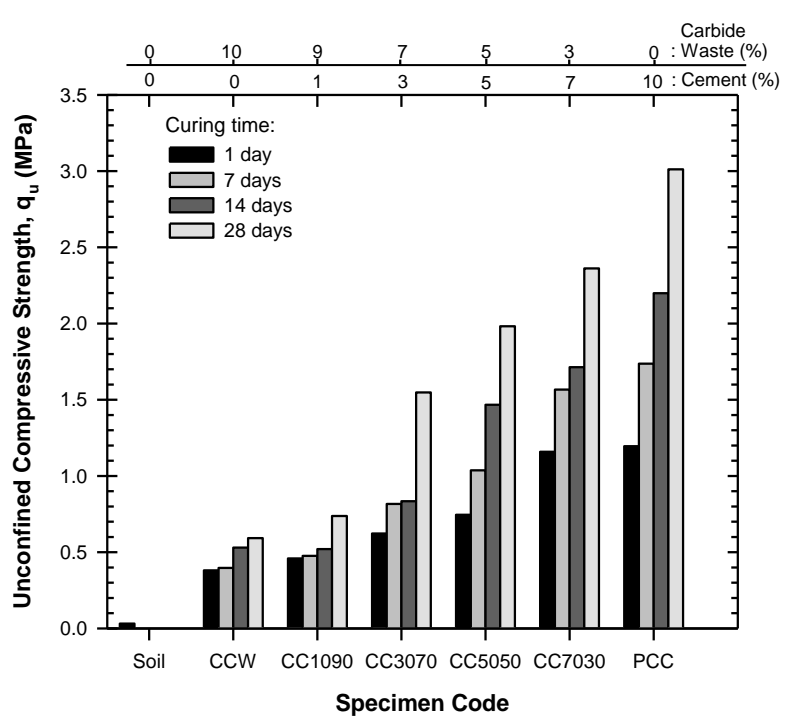

(a)

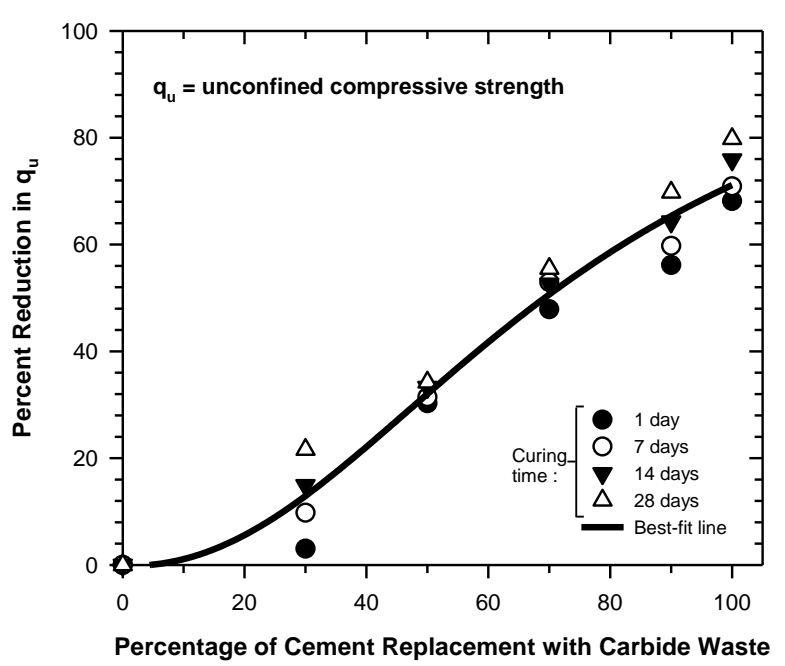

(b)

Figure 4. (a) Variation of the Unconfined Compressive Strength and Carbide Waste Content, (b) Correlation of the Cement Replacement and Percent Reduction in Unconfined Compressive Strength.

The tensile strength tends to decrease greater than one-half after 50\% cement replacement (Figure 5b). Full replacement of the cement with carbide waste caused about 90\% reduction in tensile strength. Comparing the tensile strength to unconfined compressive strength, the strength reduction in tensile was higher than the compression.

\section{Variation of Curing Time and Cement - Car- bide Waste Mixture}

Figure $6 \mathrm{a}$ and $6 \mathrm{~b}$ illustrate the variation of compressive and tensile strength with curing period respectively. As expected the compressive and tensile strength of stabilized soil with cement and cementcarbide waste mixtures gradually increased with curing age. The lines in Figure 6 are an empirical strength development that was approached by logarithm model. It was shown that the strength developed faster from the early age to seven days of curing. If the compressive strength at 28 days is defined as reference for maximum strength, then the gain of strength is about 81 to 92 percents of the maximum strength achieved at seven days of curing. After 14 days of curing, the strength rate grew slowly about 8 to 9 percent. The rate of strength development will depend upon the level of cement replacement and curing time. At the early stage, unconfined compressive strength of the carbidestabilized soil developed rapidly about $92 \%$, while the cement-stabilized soil is about $81 \%$. The result indicates that the carbide waste controlled the gain of soil strength at early stage of curing. The same characteristic was observed by Consoli et al. [5].

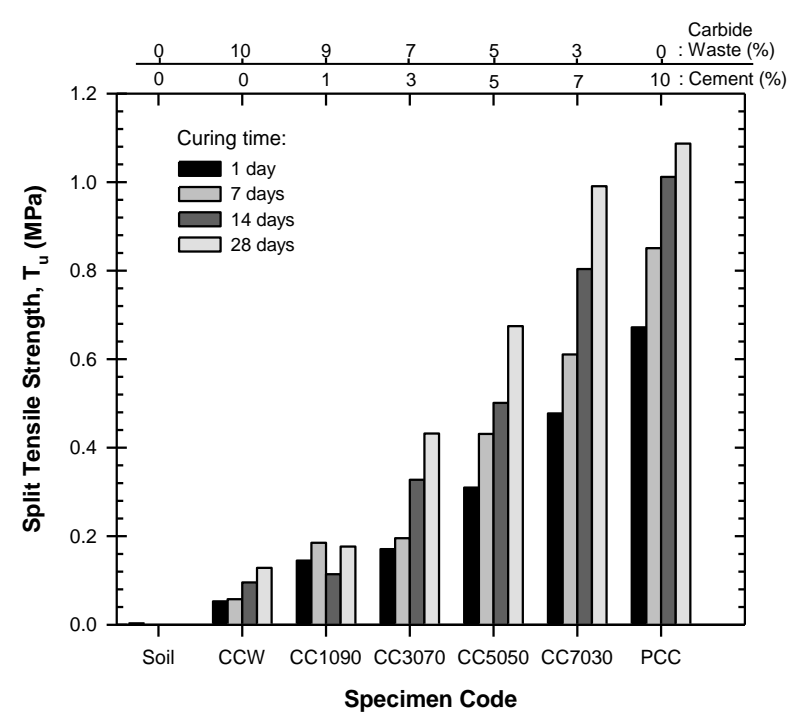

(a)

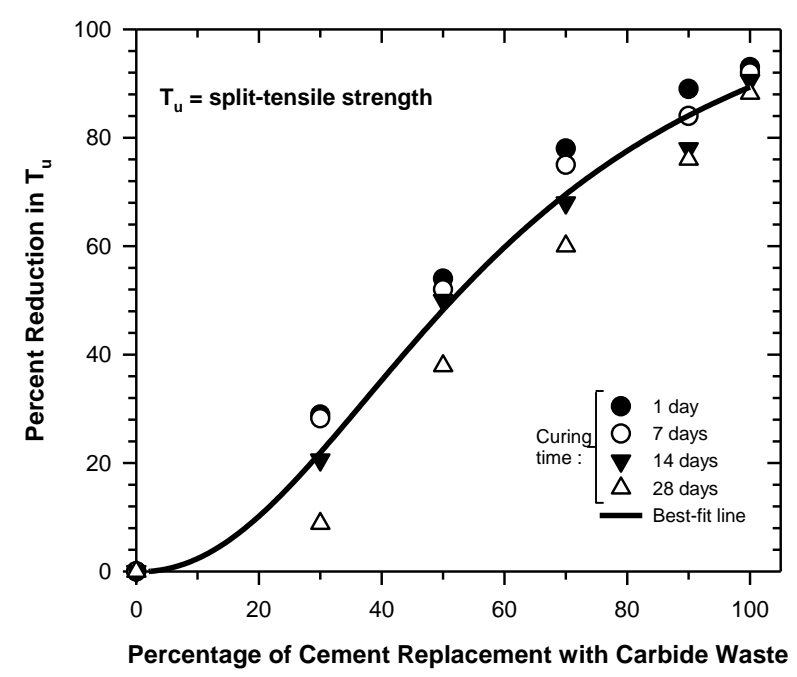

(b)

Figure 5. (a) Variation of the Split-tensile Strength with Carbide Waste Content, (b) Correlation of the Cement Replacement and Percent Reduction in Split-tensile Strength 


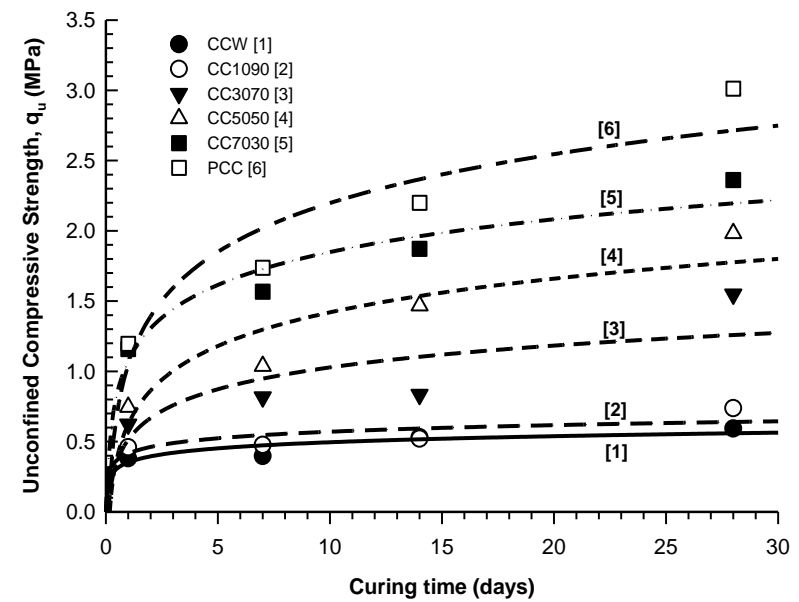

(a)

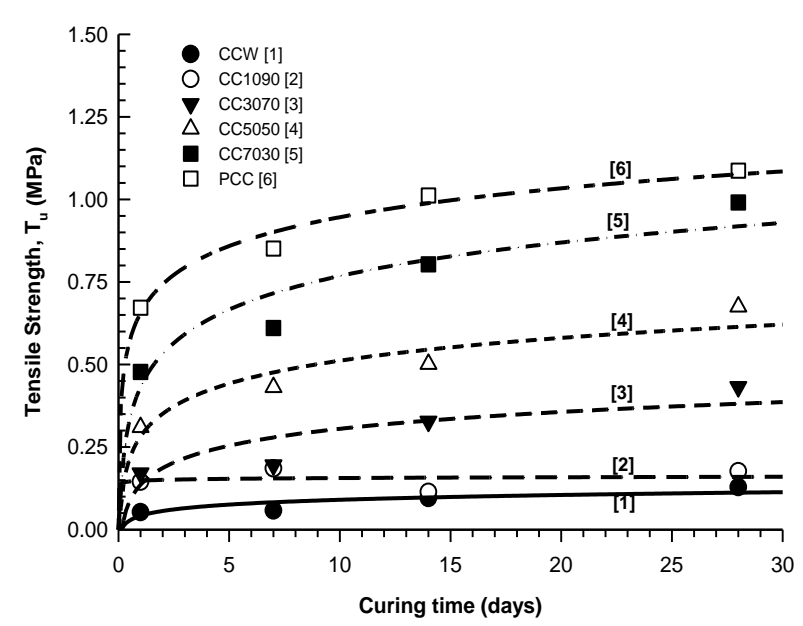

(b)

Figure 6. Relationship between Unconfined Compressive Strength (a), Split Tensile Strength (b) and Curing Time

Figure 6a shows that the compressive strengths of the cement-carbide waste specimen at one day range from 0.38 to $1.15 \mathrm{MPa}$ while that of OPC specimen was $1.19 \mathrm{MPa}$. At the age of 28 days, the unconfined compressive strength of cement-carbide waste specimen increased to $0.59-2.36 \mathrm{MPa}$ depending on the mix proportion of cement and carbide waste. In Figure $6 \mathrm{~b}$, the same trend is observed for the tensile strength of the specimens. The 28 days strength for carbide waste mix was $0.67 \mathrm{MPa}$ and $1.09 \mathrm{MPa}$ for cement mix. It is obvious that the carbide waste mix (CCW) have a lower tensile strength than cementmixed soil specimen (OPC). Cement stabilized soil still gave the highest compressive and tensile strength among the mixtures. The result shows that the tensile strength is a function only of the amount of cementitious compounds formed, which increases with curing time.

\section{Discussion}

The Indonesian standard SNI 03-3438-1994 [14] for cement stabilized road required the unconfined compressive strength after seven and 28 days of placing. The required unconfined compressive strength after seven days of mixing is $0.6 \mathrm{MPa}$ and $2.2 \mathrm{MPa}$ as subgrade and base course respectively. While the required strength after 28 days of mixing is $1.4 \mathrm{MPa}$ and $3.5 \mathrm{MPa}$ as subgrade and base course respectively. The tensile strength of cement stabilized subgrade and base course are minimum 0.2 $\mathrm{MPa}$ after seven days of curing.

Table 4 present the evaluation of the soil mixtures based on these requirements. It was found that the stabilized soils are only suitable as subgrade, except specimen CCW and CC1090. The result indicates that the carbide waste alone cannot be used for subgrade improvement, and its content to replace cement in the mixture should be less than $70 \%$.

Based on the results illustrated in Figures 4 to 5 and Table 4, it can be noted that the stabilized soil containing $3 \%$ of cement, and $7 \%$ of carbide waste (CC3070) gave minimum strength required as pavement subgrade. Increasing the cement replacement from $30 \%$ of total mixtures resulted in a lower compressive and tensile strength, but still higher than the untreated soil. The decreasing strength might be attributed to less cementitous materials in the soil - cement - carbide waste mixtures. Some researchers $[15,16]$ mentioned that elements of the oxides of $\mathrm{SiO}_{2}, \mathrm{Al}_{2} \mathrm{O}_{3}, \mathrm{Fe}_{2} \mathrm{O}_{3}$, and $\mathrm{CaO}$ were important for evaluating the cementing or pozzolanic characteristics. The cementing characteristic is

Table 4 . Evaluation of the UCS and STS Criteria for Road Based on SNI 03-3438-1994 [15]

\begin{tabular}{|c|c|c|c|c|c|c|}
\hline \multirow{2}{*}{$\begin{array}{l}\text { Curing } \\
\text { (day) }\end{array}$} & \multicolumn{6}{|c|}{ Unconfined Compressive Strength of specimens (MPa) } \\
\hline & $\mathrm{CCW}$ & CC1090 & CC3070 & CC5050 & CC7030 & $\mathrm{OPC}^{*}$ \\
\hline $\begin{array}{c}7 \\
\text { (Subgrade/Base)* }^{*}\end{array}$ & $\begin{array}{c}0.40 \\
(\mathrm{~N} / \mathrm{N})\end{array}$ & $\begin{array}{c}0.48 \\
(\mathrm{~N} / \mathrm{N})\end{array}$ & $\begin{array}{c}0.82 \\
(\mathrm{Y} / \mathrm{N})\end{array}$ & $\begin{array}{l}1.04 \\
(\mathrm{Y} / \mathrm{N})\end{array}$ & $\begin{array}{l}1.57 \\
(\mathrm{Y} / \mathrm{N})\end{array}$ & $\begin{array}{l}1.74 \\
(\mathrm{Y} / \mathrm{N})\end{array}$ \\
\hline $\begin{array}{c}28 \\
\text { (Subgrade/Base)* }^{*}\end{array}$ & $\begin{array}{c}0.59 \\
(\mathrm{~N} / \mathrm{N})\end{array}$ & $\begin{array}{c}0.74 \\
(\mathrm{~N} / \mathrm{N})\end{array}$ & $\begin{array}{l}1.55 \\
(\mathrm{Y} / \mathrm{N})\end{array}$ & $\begin{array}{l}1.98 \\
(\mathrm{Y} / \mathrm{N})\end{array}$ & $\begin{array}{l}2.36 \\
(\mathrm{Y} / \mathrm{N})\end{array}$ & $\begin{array}{l}3.01 \\
(\mathrm{Y} / \mathrm{N})\end{array}$ \\
\hline \multicolumn{7}{|c|}{ Split-tensile Strength of specimens (MPa) } \\
\hline $\begin{array}{c}7 \\
\text { (Subgrade/Base)* }\end{array}$ & $\begin{array}{c}0.06 \\
(\mathrm{~N} / \mathrm{N})\end{array}$ & $\begin{array}{c}0.19 \\
(\mathrm{~N} / \mathrm{N})\end{array}$ & $\begin{array}{l}0.20 \\
(\mathrm{Y} / \mathrm{Y})\end{array}$ & $\begin{array}{l}0.43 \\
(\mathrm{Y} / \mathrm{Y})\end{array}$ & $\begin{array}{l}0.61 \\
(\mathrm{Y} / \mathrm{Y})\end{array}$ & $\begin{array}{l}0.85 \\
(\mathrm{Y} / \mathrm{Y})\end{array}$ \\
\hline
\end{tabular}

Note: * evaluation the requirement for subgrade/base course; Y: fulfill the requirement of; N: not fulfill the requirement of 
expressed in terms of hydration or calcium ratio that is defined as the ratio of $\mathrm{CaO}$ to the summation of $\mathrm{SiO}_{2}$ and $\mathrm{Al}_{2} \mathrm{O}_{3}\left(\mathrm{CaO} /\left(\mathrm{SiO}_{2}+\mathrm{Al}_{2} \mathrm{O}_{3}\right)\right.$. The other ratio is silica ratio $\left(\mathrm{SiO}_{2} /\left(\mathrm{Al}_{2} \mathrm{O}_{3}+\mathrm{Fe}_{2} \mathrm{O}_{3}\right)\right)$ which represent the required energy to combine raw materials in a stabilization application. The calcium ratio of cement and carbide waste is 2.44 and 4.71 respectively, while the silica ratio of cement and carbide waste is 2.22 and 0.38 respectively. These ratios indicate that carbide waste was not self-cementing material since the lack of siliceous materials. Replacing higher cement content with carbide waste will result in unreacted $\mathrm{CaO}$ or liberated lime. The conversion of liberated lime into calcium silicate hydrate (C-S-H) need silica, confers enhanced strength [17]. Cetin et al. [16] indicated that larger $\mathrm{CaO}$ content, calcium and silica ratio would result in a higher bearing capacity value of the stabilized soil. However, in this study, higher carbide waste content in the mixture could not achieve higher strength. It might be the presence of carbonate (Figure 2), lower silica content and higher LOI (Table 2) in the carbide waste that detained the pozzolanic reaction in soil stabilization system. Horpibulsuk et al. [7] explained that the liberated carbide lime have a deterioration effect for soil stabilization. As the result, the unconfined compressive strength decreased gradually with the carbide waste content.

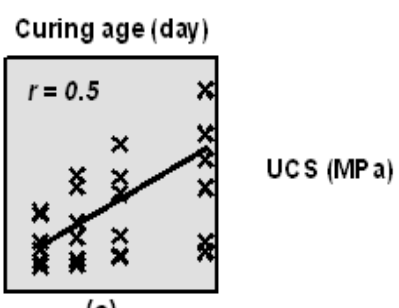

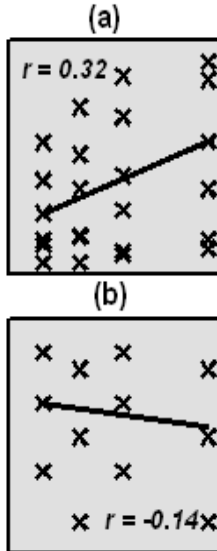

(d)

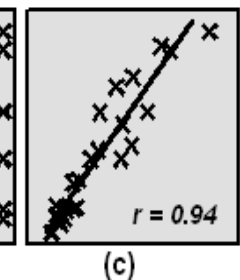

STS (MP a)

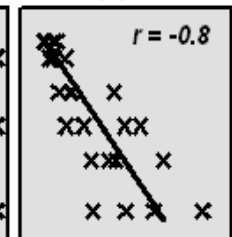

(e)

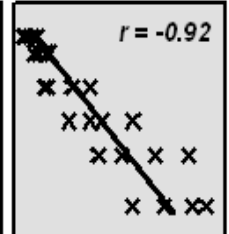

(f)
Figure 7 Correlation Matrix among the Parameters in Soil Stabilization (a) UCS and Curing Age, (b) Split Tensile Strength and Curing Age, (c) UCS and Split Tensile Strength, (d) Carbide Waste Content and Curing Age, (e) UCS and Carbide Waste Content, (f) Split Tensile Strength and Carbide Waste Content
The unconfined compression test is the most common method of strength measurement. Practically, the tensile strength can be correlated with the unconfined compressive strength. The correlation is commonly used for the mechanistic design of pavement $[12,18]$. Attempts were also made to relate statistically the unconfined compressive strength and split tensile strength of the stabilized soil and the other variables such as the curing time and carbide waste content. The statistical correlation between those variables is presented as scatter matrix graph as shown in Figure 7. Principally the r-value ranges from -1 to 1 . Two variables strongly correlated if the r-value is closer to -1 or 1 [20].

In this study, the curing age influenced the strength gained in the compressive and tensile strength of the specimens as shown in correlation curve in Figure 7a and $7 \mathrm{~b}$ respectively. There was a weak correlation between curing time and carbide waste content (Figure 7d), indicating both variables were independent. However the unconfined compressive strength and split tensile strength show very strong correlation (Figure 7c). This study showed that the split tensile strength of the cement - carbide waste mixed soil is approximately 0.43 times the unconfined compressive strength. This estimated value is higher than the lime-stabilized soil as determined by other researchers. Thompson [20] and Baghdadi et al. [21] concluded that the indirect tensile strength of limesoil mixtures was approximately 0.13 times the unconfined compressive strength. While Little [18] defined that the tensile strength of lime-soil mixtures was approximately 0.25 times the unconfined compressive strength. Muntohar and Abidin [5] stated that the plasticity index of the carbide waste stabilized soil was higher than the lime or cement stabilized soil for the same proportion of stabilizer, but lower than the untreated soil. Plasticity index is known as adhesiveness of soil particles and related to the tensile strength [2]. A higher plasticity index indicates a higher ability to adhere the soil particles. Hence, it is the possible cause of the higher tensile strength value of carbide waste-soil mixtures.

The negative r-value in Figure $7 \mathrm{e}$ and $7 \mathrm{f}$ indicated that the carbide waste content has a detrimental effect on the strength of cement-stabilized soil. A decrease in strength, which appears when the carbide waste proportion replaced cement, was caused by unsoundness due to free lime. Horpibulsuk et al. [7] also explained a similar characteristic. Krammat and Tangtermsirikul [8] explained that the excess free lime usually hydrates very slowly, causing unsoundness of the cement mixtures in the hardened state. The increasing of carbide waste will increase the free lime, thus results in burn-ability improvement of the cement and volume stability of 
the cement-soil matrix. In this study found that, replacing cement with a greater amount of carbide waste may not be beneficial for soil improvement.

\section{Conclusions}

Series of the laboratory study was conducted to investigate the feasibility of cement replacement with carbide waste in soil stabilization framework. The effects of mixtures composition and curing time on compressive and tensile strength of soil have been studied. The observations are summarized as follows:

1. Cement-stabilized clay soil contributes to the highest compressive and tensile strength among the mixtures. Replacing cement with carbide waste reduces its ability to resist the compressive and tensile stress. The carbide waste content should be less than $70 \%$ of the admixture to provide a sufficient effect on a clay subgrade.

2. In general, the strength of stabilized clay soil is higher than the untreated soil. The strength increases with the curing time. The strength developed rapidly within seven days of curing, thereafter, the strength increases marginally with the elapsed time. The tensile strength of the stabilized soil was 0.43 times of its unconfined compressive strength.

3. The Indonesian standard SNI 03-3438-1994 required the unconfined compressive strength of the subgrade to be $0.6 \mathrm{MPa}$ and $1.4 \mathrm{MPa}$ after seven days and 28 days of mixing respectively. In addition, the required tensile strength is $0.2 \mathrm{MPa}$ after seven days of curing. Based on these requirements, only the stabilized soils with cement and cement replacement less than $30 \%$ are suitable as subgrade.

\section{Acknowledgement}

The research is part of competitive research scheme of Universitas Muhammadiyah Yogyakarta in 2009/2010. The research was continued under the research grant from Ministry of Education and Culture; The Republic of Indonesia under fundamental research scheme in 2011/2012. Authors greatly appreciate for the financial supports.

\section{References}

1. Muntohar, A.S., The Swelling of Expansive Subgrade at Wates-Purworejo Roadway, STA. 8+127, Civil Engineering Dimension, 8(2), 2006, pp. 106-110.

2. Prusinski, J.R. and Bhattacharja, S., Effectiveness of Portland Cement and Lime in Stabilizing Clay Soils, Transportation Research Record, 1652, 1999, pp. 215-227, doi: 10.3141/1652-28.
3. Cardoso, F.A., Fernandes, H.C., Pileggi, R.G., Cincotto, M.A., and John, V.M., Carbide Lime and Industrial Hydrated Lime Characterization, Powder Technology, 195, 2009, pp. 143-149, doi: 10.1016/j.powtec.2009.05.017.

4. Muntohar, A.S. and Abidin, Z., A Comparative Study of Different Additive on the Index Properties of Expansive Soils, Jurnal Semesta Teknika, 4(2), 2001, pp. 59-67.

5. Consoli, N.C., Prietto, P.D.M., and Carraro, J.A.H., Behavior of Compacted Soil-Fly AshCarbide Lime Mixtures, Journal of Geotechnical and Geoenvironmental Engineering, 127, 2001, pp. 774-782, doi: 10.1061/(ASCE) 1090-0241 (2001)127:9(774).

6. Xi, Z.Y., Shu, D.L., and Wei, C., Silt Subgrade Modification and Stabilization with Ground Granulated Blast Furnace Slag and Carbide Lime in Areas with A Recurring High Groundwater, 2010 International Conference on Mechanic Automation and Control Engineering (MACE), Wuhan, China, 26-28 June 2010, pp. 2063-2067, doi: 10.1109/MACE.2010. 5536286

7. Horpibulsuk, S., Phetchuay, C., Chinkulkijniwat, A., and Cholaphatsorn, A., Strength Development in Silty Clay Stabilized with Calcium Carbide Residue and Fly Ash, Soils and Foundations, 53(4), 2013, pp. 477-486, doi: 10.1016/ j.sandf.2013.06.001.

8. Krammart, P., and Tangtermsirikul, S., A Study on Cement Made by Partially Replacing Cement Raw Materials with Municipal Solid Waste Ash and Calcium Carbide Waste, Science Asia, 29, 2003, pp. $77-84$, doi: 10.2306/scienceasia15131874.2003.29.077.

9. ASTM, Standard Practice for Classification of Soils for Engineering Purposes (Unified Soil Classification System, ASTM D2487-06, ASTM International, West Conshohocken, PA, 2006, doi: 10.1520/D2487-06.

10. ASTM, Standard Practice for Classification of Soils and Soil-Aggregate Mixtures for Highway Construction Purposes, ASTM D3282-04, ASTM International, West Conshohocken, PA, 2004a. doi: 10.1520/D3282-93R04E01.

11. ASTM, Standard Test Method for Unconfined Compressive Strength of Compacted Soil-Lime Mixtures, ASTM D5102-04, ASTM International, West Conshohocken, PA, 2004b, doi: 10.1520/ D5102-04.

12. ASTM, Standard Test Method for Splitting Tensile Strength of Cylindrical Concrete Specimens, ASTM C 496 - 96, ASTM International, West Conshohocken, PA, 1996, doi: 10.1520/ C0496-96.

13. Arellano, D. and Thompson, M.R., Stabilized Base Properties (Strength, Modulus, Fatigue) for Mechanistic-based Airport Pavement Design. Final Report, COE Report No. 4, University of Illinois at Urbana-Champaign, 1998. 
14. SNI 03-3438-1994, Tata Cara Pembuatan Stabilisasi Tanah dengan Semen Portland untuk Jalan, Badan Standarisasi Nasional, 2002.

15. Kamon, M. and Nontananandh, S., Combining Industrial Wastes with Lime for Soil Stabilisation, Journal of Geotechnical Engineering, 117(1), 1990, pp. 1-17, doi: 10.1061/(ASCE)07339410(1991)117:1(1).

16. Cetin, B., Aydilek, A.H., and Gune, Y., Stabilization of Recycled Base Materials with High Carbon Fly Ash, Resources, Conservation and Recycling, 54(11), 2010, pp. 878-892, doi: 10.1016/ j.resconrec.2010.01.007.

17. James, J., and Rao, M.S., Reaction Product of Lime and Silica from Rice Husk Ash, Cement and Concrete Research, 16, 1986, pp. 67-73, doi: 10.1016/0008-8846(86)90069-4.
18. Little, D.N., Example Problem Illustrating the Application of the National Lime Association Mixture Design and Testing Protocol (MDTP) to Ascertain Engineering Properties of Lime Treated Subgrades for Mechanistic Pavement Design/Analysis, National Lime Association, 2001.

19. Montgomery, D.C., Design and Analysis of Experiments, $5^{\text {th }}$ Edition, John Wiley \& Son's Inc., New York, 2001.

20. Thompson, M.R., The Split-Tensile Strength of Lime-Stabilized Soil, Highway Research Record, 92, 1966, pp. 69-82.

21. Baghdadi, Z.A., Fatani, M.N., and Sobban, N.A., Soil Modification by Cement Kiln Dust, Journal of Materials in Civil Engineering, 7(4), 1995, pp. 218-222, doi: 10.1061/(ASCE)0899-1561(1995)7:4 (218). 